\title{
Monitoring and management of fruitfly (Bactrocera zonata) population on peach (Pronus persica) Quetta Balochistan- Pakistan
}

Mitha Khan ${ }^{1 *}$, Shafique Ahmed Memon ${ }^{2}$, Bhai Khan Solangi ${ }^{3}$, Ghulam Jillani $^{2}$, Ameer Uddin ${ }^{1}$, Syed Jahangeer Shah ${ }^{4}$, Enayat Aziz ${ }^{4}$, Kamran Jamil $^{4}$, Naveed Ahmed ${ }^{4}$, Aeman Afzal ${ }^{5}$ and Abdul Raziq ${ }^{6}$

1. Research officer Agriculture Research Institute Baluchistan-Pakistan

2. Department of Entomology,LUAWMS at uthal Baluchistan-Pakistan

3. Department of Entomology, Sindh Agriculture University, Tandojam-Pakistan

4. Agriculture Officer Agriculture Extension Department Baluchistan-Pakistan

5. Agriculture Research fruit and Post-Harvest Quetta Baluchistan-Pakistan

6. Agriculture officer Directorate of Procurement of Supplies (Extension wing) Baluchistan-Pakistan

*Corresponding author's email: mithakhan86.mk@gmail.com

Citation

Mitha Khan, Shafique Ahmed Memon, Bhai Khan Solangi, Ghulam Jillani, Ameer Uddin, Syed Jahangeer Shah, Enayat Aziz, Kamran Jamil, Naveed Ahmed, Aeman Afzal and Abdul Raziq. Monitoring and management of fruitfly (Bactrocera zonata) population on peach (Pronus persica) Quetta Balochistan-Pakistan. Pure and Applied Biology. Vol. 9, Issue 4, pp2425-2434. http://dx.doi.org/10.19045/bspab.2020.90257

\begin{tabular}{llll}
\hline \hline Received: 04/04/2020 & Revised: 17/07/2020 & Accepted: 19/07/2020 & Online First: 24/07/2020 \\
\hline \hline
\end{tabular}

\section{Abstract}

Present investigation was conducted on the monitoring and management of fruit fly (Bactrocera zonata) population on peach in different locations of Quetta region (Hanna Orak) during 2017. The experiment consists of following IPM treatments (Sanitation + Methyl-Eugenol, without sanitation + Methyl-Eugenol, Sanitation + Protein hydrolysis baits, without sanitation + Protein hydrolysis baits, Neem Extract + Methyl-Eugenol and Neem Extract + Protein hydrolysis baits).

The results of current finding showed that peak population of Bactrocera zonata (1223.2 \pm 66.74 larvae/trap) was trapped under Methyl eugenol with sanitation Neem extract followed by Neem Extract + Methyl-Eugenol (1187.6 \pm 64.80 larvae/trap), Sanitation + Methyl-Eugenol (1153 \pm 62.84 larvae/trap), Sanitation + Protein hydrolysis baits (1064 \pm 31.40 larvae/trap), Neem Extract + Protein hydrolysis baits $(959.8 \pm 43.50$ larvae/trap), without sanitation + MethylEugenol (932 \pm 42.26 larvae/trap), without sanitation (870.97 \pm 76.76 larvae) and Without sanitation + Protein hydrolysis baits $\left(724 \pm 80.59\right.$ larvae/trap) on $30^{\text {th }}$ September. Similar trend was observed for minimum population of Bactrocera zonata trapped under different IPM treatments. Analysis of variance (ANOVA) depicted highly significant difference $(\mathrm{p}<0.05)$ in population of Bactrocera zonata trapped under different IPM treatments in all fortnight observations. On the basis of present investigation, it was observed that Bactrocera zonata highly attracted to Methyl eugenol with sanitation Neem extract followed by Neem Extract + 
Methyl-Eugenol, Sanitation + Methyl-Eugenol, Sanitation + Protein hydrolysis baits, Neem Extract + Protein hydrolysis baits, Without sanitation + Methyl-Eugenol and Without sanitation + Protein hydrolysis baits. Maximum population abundance of Bactrocera zonata were recorded at the end of September afterwards the population simultaneously declined upto end of October.

Keywords: Monitoring; Management; Fruitfly Introduction

Every people every time demand healthy and safe nutritious fruit. In Pakistan there is a greater demand of fruit. That can only met by fruit management from insect pests. Fruit flies are the most important pests because of their quarantine importance. Different insect pest species attacking on delicious fruit but fruit fly (Tepheritidae, Diptera) cause greater economic losses to fruit in Pakistan [1]. Fruit fly reduces both quality and quantity of fruit when female lay their eggs inside the fruit after that hatched maggots feed pulp and render them unfit for human consumption. At the puncture point fruit start rotting. The losses caused due to various species of fruit fly. In scientific literature reported oriental fruit fly $(B$. dorsalis) is the serious pest which caused 5 - 100 percent loss of various fruit [2]. Highest loss 80 Percent in guava fruit was reported by Kafi [3]. Guava fruit fly (B. correcta) is the serious pest of guava and another various fruit [4] reported 60 to 80 percent loss due to guava fruit fly.

Peach fruit fly ( $B$. zonata) is the another serious pest of various fruit which found abundantly in all climatic region of Pakistan and cause 3 to 100 percent loss in different fruit [2]. A loss to the tune of 25 to 50 percent occurred in mango fruit every year by $B$. zonata and $B$. dorsalis [2]. .The fruit flies [Bactroceradorsalis (Hendle), $B$. zonata(Saunders)] damage was observed on fruits from October to January with maximum infestation during $\mathrm{s}$ second fortnight of December. This is in agreement with the findings of Kumar et al. [5].

Export of mango and other soft fruits from Pakistan is under threat due to fruit fly infestations. A fruit fly management model

was developed, demonstrated on 500 acres mango orchards successfully achieving $95 \%$ control and published by PARC scientists under a National Coordinated Project on Integrated Pest Management of Fruit flies in Pakistan. The model consisted of the application of MAT, BAT, Sanitation and neem seed extract [6]. It was successfully demonstrated in guava plantations at large scale.

Peach belongs to the genus: Persica. Scientific name: Persicadominica. Peach thought to have originated in the Central American rain forests, probably in Mexico and Belize and bear fruit twice a year. Today, its cultivation has spread all over the tropical belt and is being grown as a major commercial crop in India, Sri Lanka, Indonesia and Malaysia. Peach is another popular sub-tropical fruit in line with Apple almond, etc .It is composes of soft easily digestible pulp made of simple sugars like fructose and sucrose. Peach is delicious fruit crop of tropical and sub-tropical countries and grown commercially for making chewing gum. The consumption of peach is recommended in herbal medicine as it has an uncountable number of medicinal uses. In Pakistan, the mature fruits are also used for making jams as these provide a valuable source of raw material for the manufacture of industrial glucose, pectin and natural fruit jellies. They are also canned as slices. Peach is a tropical and subtropical fruit of Pakistan and can be grown from sea level up to 1600 2000 meters. The mountainous climate is best suited to this plant. This fruit crop was introduced in Pakistan from India about thirty year ago .This crop cultivated in Balochistan distract (Mastung, Pishin, Loralai Kanmahtorzai) are exceptionally 
suited to its growing on the basis of soil and climatic requirements [7]. High quantity and quality losses caused due to the insect pests and disease. Including insect pest larvae of twig borer, scales, mealy bug, aphid and fruit flies. Fruit flies (Diptera: Tephritidae) incur most of the damage fruit of peach.

\section{Materials and methods}

The research work was undertaken in peach orchards in and around Quetta. Monitoring of fruit fly population was done in various farm around Quetta whereas its management studies was undertaken in Achakzai Peach form Hanna lake. Monitoring of the peach fruit fly population was done through fortnight sampling in two orchard $30 \mathrm{~km}$ away from each other. For this purpose five plastic traps having methyl Eugenol and 5\% malathion or available insecticide were installed in each orchard at fortnightly interval and population of trapped fruit fly adults counted during August to September and until the harvest of the fruit.

\section{Management of peach fruit fly}

Following treatment was applied in the peach form for management of fruit fly during August to September and until the harvest of fruit.

1. Methyl eugenol traps with Sanitation

2. Methyl eugenol without Sanitation.

3. Protein hydrolysate baits with Sanitation.

4. Protein hydrolysate baits without Sanitation.

5. Methyl eugenol with Neem extract.

6. Protein hydrolysate baits with Neem extract.

7. Methyl eugenol with Sanitation and Neem extract.

Male annihilation through pheromone (methyl Eugenol + contact insecticide) baited wooden blocks re-charged after every 10 days

Plywood blocks measuring (3x3 inch) soaked in the mixture of (methyl eugenol $+5 \%$ Malathion/available contact insecticide) which was fixed on the tree at $4.5 \mathrm{ft}$ height. For population monitoring 5 traps was used. These was recharged after 10 days.

Female flies controlled by bait application technique through regular sprays of the bait (protein hydrolysate mixed with $10 \%$ available stomach poison) during fruit fly season at 10 days interval

Bait spray is a preparation of $3 \mathrm{ml}$ stomach poison and $30 \mathrm{ml}$ commercial protein hydrolysate in $1 \mathrm{~L}$ water. The mixtures 7.6 liter was used with knapsack sprayer weekly from the start of fruit formation till harvest. Four blocks with 5 traps was used. In each block 1 trap was used at the height of 4.5 feet. Bait sprays was applied at the underside of the tree canopy.

Application of 2\% Neem seed extract on the most susceptible varieties at 10 days interval during fruit ripening.

Neem seed is abundantly available in Jaffarabad district. Two percent of Neem seed extract was prepared from $2 \mathrm{Kg}$ Neem seed powder along with 30gm detergent. The powder of Neem seed was wrapped in a muslin cloth and dipped in 4-5L hot water. After 15-20 hours, the concentrate was squeezed out and diluted by adding water. Only 3 sprays of Neem seed extract at an interval of 10 days was applied in order to repel fruit fly from ripening peach. This material is an effective repellent against fruit flies.

Results

Population of Bactrocera zonata trapped by Methyl-Eugenol with and without sanitation

Results (Table 1) indicates that on $15^{\text {th }}$ August the population of Bactrocera zonata trapped by without Sanitation + MethylEugenol was $728 \pm 67.55$ larvae/trap which was further increased upto $790 \pm 87.75$ and $990 \pm 78.10$ larvae/trap on $30^{\text {th }}$ August and $15^{\text {th }}$ September and the population reached at peak level of $1153 \pm 62.84$ larvae/trap on $30^{\text {th }}$ September, afterwards the population linearly dropped and reached at 660 \pm 54.31 
and 546.6 \pm 55.06 larvae/trap on $15^{\text {th }}$ October and $30^{\text {th }}$ October, respectively. However, the population of Bactrocera zonata trapped by Sanitation + Methyl-Eugenol was $576 \pm 53.72$ larvae/trap on $15^{\text {th }}$ August which was further increased upto $638 \pm 87.20$ and $821 \pm 72.32$ larvae/trap on $30^{\text {th }}$ August and $15^{\text {th }}$ September and the population reached at peak level of $932 \pm 42.26$ larvae/trap on $30^{\text {th }}$ September, afterwards the population linearly dropped and reached at $462 \pm 51.71$ and $386.6 \pm 73.76$ larvae/trap on $15^{\text {th }}$ October and $30^{\text {th }}$ October, respectively. On the basis of statistical analysis of the data, there was highly significant difference in population of Bactrocera zonata trapped by Sanitation + Methyl-Eugenol and without sanitation + Methyl-Eugenol in all fortnight observations. Furthermore, significantly higher population of Bactrocera zonata was observed under without Sanitation + Methyl-Eugenol as compared to Sanitation + Methyl-Eugenol on $30^{\text {th }}$ September.

Table 1. Mean \pm SE population of Bactrocera zonata trapped by Methyl-Eugenol with and without sanitation

\begin{tabular}{|c|c|c|}
\hline Date & $\begin{array}{c}\text { Plot-1 } \\
\text { (Sanitation + Methyl-Eugenol) }\end{array}$ & $\begin{array}{c}\text { Plot-2 } \\
\text { (Without sanitation+Methyl-Eugenol) }\end{array}$ \\
\hline $15^{\text {th }}$ August & $576 \pm 53.72 \mathrm{ef}$ & $728 \pm 67.55 \mathrm{de}$ \\
\hline $30^{\text {th }}$ August & $638 \pm 87.20 \mathrm{f}$ & $790 \pm 87.75 \mathrm{~cd}$ \\
\hline $15^{\text {th }}$ September & $821 \pm 72.32 \mathrm{c}$ & $990 \pm 78.10 \mathrm{~b}$ \\
\hline $30^{\text {th }}$ September & $932 \pm 42.26 \mathrm{~b}$ & $1153 \pm 62.84 \mathrm{a}$ \\
\hline $15^{\text {th }}$ October & $462 \pm 51.71 \mathrm{hi}$ & $660 \pm 54.31 \mathrm{ef}$ \\
\hline $30^{\text {th }}$ October & $386.6 \pm 73.76 \mathrm{i}$ & $546.6 \pm 55.06 \mathrm{gh}$ \\
\hline
\end{tabular}

$\mathrm{SE} \pm=43.190, \mathrm{LSD} 0.05=87.044, \mathrm{P}$-value $=0.0000^{*}, * *=$ highly significant

Different alphabets among the mean values shows significant difference at $<0.05$ probability level

Population of Bactrocera zonata trapped by protein hydrolysis baits with and without sanitation

Results (Table 2) indicates that on $15^{\text {th }}$ August the population of Bactrocera zonata trapped by without sanitation + Protein hydrolysis baits was $629 \pm 31.24$ larvae/trap which was further increased upto $752 \pm 27.82$ and $972 \pm 39.16$ larvae/trap on $30^{\text {th }}$ August and $15^{\text {th }}$ September and the population reached at peak level of $1064 \pm 31.40$ larvae/trap on $30^{\text {th }}$ September, afterwards the population linearly dropped and reached at $540 \pm 20.73$ and $415.8 \pm 33.56$ larvae/trap on $15^{\text {th }}$ October and $30^{\text {th }}$ October, respectively. However, the population of Bactrocera zonata trapped by sanitation + Protein hydrolysis baits was $416 \pm 33.55$ larvae/trap on $15^{\text {th }}$ August which was further increased upto $476 \pm 55.10$ and $558 \pm 57.56$ larvae/trap on $30^{\text {th }}$ August and $15^{\text {th }}$ September and the population reached at peak level of $724 \pm 80.59$ larvae/trap on $30^{\text {th }}$ September, afterwards the population linearly dropped and reached at $298 \pm 41.76$ and $232 \pm 33.37$ larvae/trap on $15^{\text {th }}$ October and $30^{\text {th }}$ October, respectively. On the basis of statistical analysis of the data, there was highly significant difference in population of Bactrocera zonata trapped by sanitation + Protein hydrolysis baits and without sanitation + Protein hydrolysis baits in all fortnight observations. Furthermore, significantly higher population of Bactrocera zonata was observed under without sanitation + Protein hydrolysis baits as compared to sanitation + Protein hydrolysis baits on $30^{\text {th }}$ September. 
Table 2. Mean \pm SE population of Bactrocera zonata trapped by Protein hydrolysis baits with and without sanitation

\begin{tabular}{|c|c|c|}
\hline Date & $\begin{array}{c}\text { Plot-1 } \\
\text { (Sanitation }+ \text { Protein hydrolysis } \\
\text { baits) }\end{array}$ & $\begin{array}{c}\text { Plot-2 } \\
\text { (Without sanitation+ Protein hydrolysis } \\
\text { baits) }\end{array}$ \\
\hline $15^{\text {th }}$ August & $416 \pm 33.55 \mathrm{~g}$ & $629 \pm 31.24 \mathrm{~d}$ \\
\hline $30^{\text {th }}$ August & $476 \pm 55.10 \mathrm{f}$ & $752 \pm 27.82 \mathrm{c}$ \\
\hline $15^{\text {th }}$ September & $558 \pm 57.56 \mathrm{e}$ & $972 \pm 39.16 \mathrm{~b}$ \\
\hline $30^{\text {th }}$ September & $724 \pm 80.59 \mathrm{c}$ & $1064 \pm 31.40 \mathrm{a}$ \\
\hline $15^{\text {th }}$ October & $298 \pm 41.76 \mathrm{~h}$ & $540 \pm 20.73 \mathrm{e}$ \\
\hline $30^{\text {th }}$ October & $232 \pm 33.37 \mathrm{i}$ & $415.8 \pm 33.56 \mathrm{~g}$ \\
\hline
\end{tabular}

SE $\pm=25.232$, LSD $0.05=50.852$, P-value $=0.0000 * *, * *=$ highly significant

Different alphabets among the mean values shows significant difference at $<0.05$ probability level

Population of Bactrocera zonata trapped by Neem extract + Methyl-Eugenol and Neem extract + protein hydrolysis baits Results (Table 3) indicates that on $15^{\text {th }}$ August the population of Bactrocera zonata trapped by Neem Extract + Methyl-Eugenol was $749.8 \pm 69.48$ larvae/trap which was further increased upto $813.6 \pm 90.42$ and 1019.6 \pm 80.39 larvae/trap on $30^{\text {th }}$ August and $15^{\text {th }}$ September and the population reached at peak level of $1187.6 \pm 64.80$ larvae/trap on $30^{\text {th }}$ September, afterwards the population linearly dropped and reached at $679.8 \pm 55.96$ and $563 \pm 56.78$ larvae/trap on $15^{\text {th }}$ October and $30^{\text {th }}$ October, respectively. However, the population of Bactrocera zonata trapped by Neem Extract + Protein hydrolysis baits was $593.2 \pm 55.34$ larvae/trap on $15^{\text {th }}$ August which was further increased upto $657 \pm 89.74$ and 845.6 \pm 74.52 larvae/trap on $30^{\text {th }}$ August and $15^{\text {th }}$ September and the population reached at peak level of 959.8 \pm 43.50 larvae/trap on $30^{\text {th }}$ September, afterwards the population linearly dropped and reached at 475.6 \pm 53.21 and 398.2 \pm 75.91 larvae/trap on $15^{\text {th }}$ October and $30^{\text {th }}$ October, respectively. On the basis of statistical analysis of the data, there was highly significant in population of Bactrocera zonata trapped by Neem Extract + MethylEugenol and Neem Extract + Protein hydrolysis baits in all fortnight observations. Furthermore, significantly higher population of Bactrocera zonata was observed under Neem Extract + Methyl-Eugenol as compared to Neem Extract + Protein hydrolysis baits on $30^{\text {th }}$ September.

Table 3. Mean \pm SE population of Bactrocera zonata trapped by Neem Extract+MethylEugenol and Neem Extract + Protein hydrolysis baits

\begin{tabular}{|c|c|c|}
\hline Date & $\begin{array}{c}\text { Plot-1 } \\
\text { (Neem Extract + Methyl-Eugenol) }\end{array}$ & $\begin{array}{c}\text { Plot-2 } \\
\text { (Neem Extract + Protein hydrolysis baits) }\end{array}$ \\
\hline $15^{\text {th }}$ August & $749.8 \pm 69.48 \mathrm{de}$ & $593.2 \pm 55.34 \mathrm{fg}$ \\
\hline $30^{\text {th }}$ August & $813.6 \pm 90.42 \mathrm{~cd}$ & $657 \pm 89.74 \mathrm{f}$ \\
\hline $15^{\text {th }}$ September & $1019.6 \pm 80.39 \mathrm{~b}$ & $845.6 \pm 74.52 \mathrm{c}$ \\
\hline $30^{\text {th }}$ September & $1187.6 \pm 64.80 \mathrm{a}$ & $959.8 \pm 43.50 \mathrm{~b}$ \\
\hline $15^{\text {th }}$ October & $679.8 \pm 55.96 \mathrm{ef}$ & $475.6 \pm 53.21 \mathrm{hi}$ \\
\hline $30^{\text {th }}$ October & $563 \pm 56.78 \mathrm{gh}$ & $398.2 \pm 75.91 \mathrm{i}$ \\
\hline
\end{tabular}

$\mathrm{SE} \pm=44.469, \mathrm{LSD} 0.05=89.621, \mathrm{P}$-value $=0.0000 * *, * *=$ highly significant

Different alphabets among the mean values shows significant difference at $<0.05$ probability level 
Population of Bactrocera zonata trapped by Methyl-Eugenol with sanitation Neem extract

Results (Table 4) indicates that on $15^{\text {th }}$ August the population of Bactrocera zonata trapped by without sanitation was $772.29 \pm 71.57$ larvae/trap which was further increased upto 838.01 \pm 93.13 and $1050.2 \pm 82.80$ larvae/trap on $30^{\text {th }}$ August and $15^{\text {th }}$ September and the population reached at peak level of $1223.2 \pm 66.74$ larvae/trap on $30^{\text {th }}$ September, afterwards the population linearly dropped and reached at $700.19 \pm 57.64$ and $579.89 \pm 58.49$ larvae/trap on $15^{\text {th }}$ October and $30^{\text {th }}$ October, respectively. However, the population of Bactrocera zonata trapped by without sanitation was $611.00 \pm 57.00$ larvae/trap on $15^{\text {th }}$ August which was further increased upto $\quad 676.71 \pm 92.43$ and $870.97 \pm 76.76$ larvae/trap on $30^{\text {th }}$ August and $15^{\text {th }}$ September and the population reached at peak level of $988.59 \pm 44.81$ larvae/trap on $30^{\text {th }}$ September, afterwards the population linearly dropped and reached at $489.87 \pm 54.81$ and $410.15 \pm 78.19$ larvae/trap on $15^{\text {th }}$ October and $30^{\text {th }}$ October, respectively. On the basis of statistical analysis of the data, there was highly significant difference in population of Bactrocera zonata trapped by MethylEugenol with sanitation Neem Extract in all fortnight observations. Furthermore, significantly higher population of Bactrocera zonata was observed under without sanitation as compared to sanitation with Methyl-Eugenol on $30^{\text {th }}$ September.

Table 4. Mean \pm SE population of Bactrocera zonata trapped by Methyl-Eugenol with sanitation Neem Extract

\begin{tabular}{|c|c|c|}
\hline Date & $\begin{array}{c}\text { Plot-1 } \\
\text { (Methyl-Eugenol with sanitation Neem Extract) }\end{array}$ & $\begin{array}{c}\text { Plot-2 } \\
\text { (without sanitation) }\end{array}$ \\
\hline $15^{\text {th }}$ August & $611.00 \pm 57.00 \mathrm{~cd}$ & $772.29 \pm 71.57 \mathrm{~cd}$ \\
\hline $30^{\text {th }}$ August & $676.71 \pm 92.43 \mathrm{bc}$ & $838.01 \pm 93.13 \mathrm{bc}$ \\
\hline $15^{\text {th }}$ September & $870.97 \pm 76.76 \mathrm{ab}$ & $1050.2 \pm 82.80 \mathrm{ab}$ \\
\hline $30^{\text {th }}$ September & $988.59 \pm 44.81 \mathrm{a}$ & $1223.2 \pm 66.74 \mathrm{a}$ \\
\hline $15^{\text {th }}$ October & $489.87 \pm 54.81 \mathrm{~cd}$ & $700.19 \pm 57.64 \mathrm{~cd}$ \\
\hline $30^{\text {th }}$ October & $410.15 \pm 78.19 \mathrm{~d}$ & $579.89 \pm 58.49 \mathrm{~d}$ \\
\hline
\end{tabular}

SE $\pm=33.851, \mathrm{LSD} 0.05=64.554, \mathrm{P}$-value $=0.0000 * *, * *=$ highly significant

Different alphabets among the mean values shows significant difference at $<0.05$ probability level

Comparative population of Bactrocera zonata trapped under different IPM treatments

Results (Table 5) indicated that maximum population of Bactrocera zonata $(1223.2 \pm 66.74$ larvae/trap) was trapped under Methyl eugenol with sanitation Neem extract followed by Neem Extract + MethylEugenol (1187.6 $\pm 64.80 \quad$ larvae/trap), Sanitation + Methyl-Eugenol (1153 \pm 62.84 larvae/trap), Sanitation + Protein hydrolysis baits $\quad(1064 \pm 31.40 \quad$ larvae/trap), Neem Extract + Protein hydrolysis baits
(959.8 $\pm 43.50 \quad$ larvae/trap), Without sanitation + Methyl-Eugenol $(932 \pm 42.26$ larvae/trap), without sanitation $(870.97 \pm 76.76$ larvae $)$ and Without sanitation + Protein hydrolysis baits (724 \pm 80.59 larvae/trap) on $30^{\text {th }}$ September. Similar trend was observed for minimum population of Bactrocera zonata trapped under different IPM treatments. Analysis of variance (ANOVA) depicted highly significant difference $(\mathrm{p}<0.05)$ in population of Bactrocera zonata trapped under different IPM treatments in all fortnight observations. 
Table 5. Comparative (Mean \pm SE) population of Bactrocera zonata trapped under different IPM treatments

\begin{tabular}{|c|c|c|c|c|c|c|c|c|}
\hline Date & $\begin{array}{c}\text { Plot-1 } \\
\text { (Sanitation } \\
\text { + Methyl- } \\
\text { Eugenol) }\end{array}$ & $\begin{array}{c}\text { Plot-2 } \\
\text { (Without } \\
\text { sanitation+ } \\
\text { Methyl- } \\
\text { Eugenol) }\end{array}$ & $\begin{array}{c}\text { Plot-1 } \\
\text { (Sanitation } \\
\text { + Protein } \\
\text { hydrolysis } \\
\text { baits) }\end{array}$ & $\begin{array}{c}\text { Plot-2 } \\
\text { (Without } \\
\text { sanitation+ } \\
\text { Protein } \\
\text { hydrolysis } \\
\text { baits) }\end{array}$ & $\begin{array}{c}\text { Plot-1 } \\
\text { (Neem } \\
\text { Extract + } \\
\text { Methyl- } \\
\text { Eugenol) }\end{array}$ & $\begin{array}{c}\text { Plot-2 } \\
\text { (Neem } \\
\text { Extract + } \\
\text { Protein } \\
\text { hydrolysis } \\
\text { baits) }\end{array}$ & $\begin{array}{c}\text { Plot-1 } \\
\text { (Methyl- } \\
\text { Eugenol with } \\
\text { sanitation } \\
\text { Neem Extract) }\end{array}$ & $\begin{array}{c}\text { Plot-2 } \\
\text { (without } \\
\text { sanitation) }\end{array}$ \\
\hline $\begin{array}{c}15^{\text {th }} \\
\text { August }\end{array}$ & $576 \pm 53.72 \mathrm{ef}$ & $728 \pm 67.55 \mathrm{de}$ & $416 \pm 33.55 \mathrm{~g}$ & $629 \pm 31.24 \mathrm{~d}$ & $593.2 \pm 55.34 \mathrm{fg}$ & $749.8 \pm 69.48 \mathrm{de}$ & $611.00 \pm 57.00 \mathrm{~cd}$ & $772.29 \pm 71.57 \mathrm{~cd}$ \\
\hline $\begin{array}{c}30^{\text {th }} \\
\text { August }\end{array}$ & $638 \pm 87.20 \mathrm{f}$ & $790 \pm 87.75 \mathrm{~cd}$ & $476 \pm 55.10 \mathrm{f}$ & $752 \pm 27.82 \mathrm{c}$ & $657 \pm 89.74 f$ & $813.6 \pm 90.42 \mathrm{~cd}$ & $676.71 \pm 92.43 b c$ & $838.01 \pm 93.13 b c$ \\
\hline $\begin{array}{c}15^{\text {th }} \\
\text { September }\end{array}$ & $821 \pm 72.32 \mathrm{c}$ & $990 \pm 78.10 \mathrm{~b}$ & $558 \pm 57.56 \mathrm{e}$ & $972 \pm 39.16 b$ & $845.6 \pm 74.52 \mathrm{c}$ & $1019.6 \pm 80.39 b$ & $870.97 \pm 76.76 \mathrm{ab}$ & $1050.2 \pm 82.80 \mathrm{ab}$ \\
\hline $\begin{array}{c}30^{\text {th }} \\
\text { September }\end{array}$ & $932 \pm 42.26 \mathrm{~b}$ & $1153 \pm 62.84 \mathrm{a}$ & $724 \pm 80.59 c$ & $1064 \pm 31.40 \mathrm{a}$ & $959.8 \pm 43.50 \mathrm{~b}$ & $1187.6 \pm 64.80 \mathrm{a}$ & $988.59 \pm 44.81 \mathrm{a}$ & $1223.2 \pm 66.74 a$ \\
\hline $\begin{array}{c}15^{\text {th }} \\
\text { October }\end{array}$ & $462 \pm 51.71 \mathrm{hi}$ & $660 \pm 54.31 \mathrm{ef}$ & $298 \pm 41.76 h$ & $540 \pm 20.73 \mathrm{e}$ & $475.6 \pm 53.21 \mathrm{hi}$ & $679.8 \pm 55.96 \mathrm{ef}$ & $489.87 \pm 54.81 \mathrm{~cd}$ & $700.19 \pm 57.64 \mathrm{~cd}$ \\
\hline $\begin{array}{c}30^{\text {th }} \\
\text { October }\end{array}$ & $386.6 \pm 73.76 \mathrm{i}$ & $546.6 \pm 55.06 \mathrm{gh}$ & $232 \pm 33.37 i$ & $415.8 \pm 33.56 \mathrm{~g}$ & $398.2 \pm 75.91 \mathrm{i}$ & $563 \pm 56.78 \mathrm{gh}$ & $410.15 \pm 78.19 \mathrm{~d}$ & $579.89 \pm 58.49 d$ \\
\hline $\mathrm{SE} \pm$ & \multicolumn{2}{|c|}{43.190} & \multicolumn{2}{|c|}{25.232} & \multicolumn{2}{|c|}{44.469} & \multicolumn{2}{|c|}{33.851} \\
\hline LSD 0.05 & \multicolumn{2}{|c|}{87.044} & \multicolumn{2}{|c|}{50.852} & \multicolumn{2}{|c|}{89.621} & \multicolumn{2}{|c|}{64.554} \\
\hline $\mathrm{P}$-value & \multicolumn{2}{|c|}{$0.0000^{* *}$} & \multirow{2}{*}{\multicolumn{2}{|c|}{$\begin{array}{c}0.0000 * * \\
\text { hishly }\end{array}$}} & \multirow{2}{*}{\multicolumn{2}{|c|}{$0.0000^{* *}$}} & \multicolumn{2}{|c|}{$0.0000^{* *}$} \\
\hline$* *$ & \multicolumn{2}{|c|}{ highly significant } & & & & & \multicolumn{2}{|c|}{ highly significant } \\
\hline
\end{tabular}

Different alphabets among the mean values shows significant difference at $<0.05$ probability level 
Overall population and percentage of Bactrocera zonata trapped by MethylEugenol with and without sanitation

Results in (Table 6) showed that maximum population and percentage of Bactrocera zonata was recorded in plot-2 (without sanitation + methyl-eugenol) as compared to plot-1 (sanitation + methyl eugenol).

Table 6. Overall population and percentage of Bactrocera zonata trapped by MethylEugenol with and without sanitation

\begin{tabular}{|c|c|c|}
\hline Variables & $\begin{array}{c}\text { Plot-1 } \\
\text { (Sanitation + Methyl-Eugenol) }\end{array}$ & $\begin{array}{c}\text { Plot-2 } \\
\text { (Without sanitation+Methyl-Eugenol) }\end{array}$ \\
\hline Total population & 3815.6 & 4867.6 \\
\hline Percentage & $44.04 \%$ & $56.18 \%$ \\
\hline
\end{tabular}

Overall population and percentage of Bactrocera zonata trapped by Protein hydrolysis baits with and without sanitation

Results in (Table 7) showed that maximum population and percentage of Bactrocera zonata was recorded in plot-2 (without sanitation + protein hydrolysis baits) as compared to plot-1 (sanitation + protein hydrolysis baits).

Table 7. Overall population and percentage of Bactrocera zonata trapped by Protein hydrolysis baits with and without sanitation

\begin{tabular}{|c|c|c|}
\hline Variables & $\begin{array}{c}\text { Plot-1 } \\
\text { (Sanitation + Protein hydrolysis } \\
\text { baits) }\end{array}$ & $\begin{array}{c}\text { Plot-2 } \\
\text { (Without sanitation+ Protein hydrolysis } \\
\text { baits) }\end{array}$ \\
\hline $\begin{array}{c}\text { Total } \\
\text { population }\end{array}$ & 2704 & 4372.8 \\
\hline Percentage & $38.20 \%$ & $61.79 \%$ \\
\hline
\end{tabular}

Overall population and percentage of Bactrocera zonata trapped by Neem extract+Methyl-Eugenol and Neem extract + Protein hydrolysis baits

Results in (Table 8) showed that maximum population and percentage of Bactrocera zonata was recorded in plot-1 (neem extract + methyl-eugenol) as compared to plot-2 (neem extract + protein hydrolysis baits).
Overall population and percentage of Bactrocera zonata trapped by MethylEugenol with sanitation Neem extract Results in (Table 9) showed that maximum population and percentage of Bactrocera zonata was recorded in plot-2 (without sanitation) as compared to plot-1 (methyleugenol with sanitation neem extract).

Table 8. Overall population and percentage of Bactrocera zonata trapped by Neem Extract+Methyl-Eugenol and Neem Extract + Protein hydrolysis baits

\begin{tabular}{|c|c|c|}
\hline Variables & $\begin{array}{c}\text { Plot-1 } \\
\text { (Neem Extract + Methyl-Eugenol) }\end{array}$ & $\begin{array}{c}\text { Plot-2 } \\
\text { (Neem Extract + Protein hydrolysis baits) }\end{array}$ \\
\hline $\begin{array}{c}\text { Total } \\
\text { population }\end{array}$ & 5013.4 & 3929.4 \\
\hline Percentage & $56.06 \%$ & $43.93 \%$ \\
\hline
\end{tabular}


Table 9. Overall population and percentage of Bactrocera zonata trapped by MethylEugenol with sanitation Neem extract

\begin{tabular}{|c|c|c|}
\hline Variables & $\begin{array}{c}\text { Plot-1 } \\
\text { (Methyl-Eugenol with sanitation Neem Extract) }\end{array}$ & $\begin{array}{c}\text { Plot-2 } \\
\text { (without sanitation) }\end{array}$ \\
\hline Total population & 4047.29 & 5163.78 \\
\hline Percentage & $43.93 \%$ & $56.06 \%$ \\
\hline
\end{tabular}

\section{Discussion}

The finding of the present study showed that Bactrocera zonata highly attracted to Methyl eugenol with sanitation Neem extract followed by Neem Extract + Methyl-Eugenol, Sanitation + Methyl-Eugenol, Sanitation + Protein hydrolysis baits, Neem Extract + Protein hydrolysis baits, Without sanitation + Methyl-Eugenol and Without sanitation + Protein hydrolysis baits. Maximum population abundance of Bactrocera zonata were recorded at the end of September afterwards the population simultaneously declined upto end of October. Solangi [8] reported that methyl eugenol pheromone traps installed at $2 \mathrm{~m}$ height resulted in highest $B$. zonata and $B$. dorsalis catches at Hyderabad (1428.4 \pm 260.04$)$, at Larkana (2208.4 \pm 327.44$)$ as well as at Mirpurkhas 1595.6 \pm 264.41 , followed by surface installed, and 1 meter or 3 meter trap heights. Under Hyderabad ecological conditions, the $B$. zonata starts its rapid development from the month of May and sustains upto the month of September with certain fluctuation at Tandojam. The fruit fly population sharply decreased in October.

According to the findings of Bateman [9] reported that tephritid fruit flies are serious pests in Mauritius, of which Bactrocera zonata (Saunders) (Diptera: Tephritidae) is one. One of the pathogens of fruit flies is Beauveria bassiana (Balsamo) Vuillemin; the introduction of this entomopathogen into the wild fly population would be beneficial for suppression of fruit fly populations. Five releases were made to study the dispersal behaviour and survival of sterile $B$. zonata males either treated or untreated with dry conidia of $B$. bassiana, in vegetable plantations bordered with papaya and mango trees in northern Mauritius from April 2010 to
December 2012. The flies used were reared for $\approx 172$ generations in the laboratory. Results showed that the dispersal behaviour and postrelease survival were different for the two types of sterile males. Recapture rates of $B$. bassiana-treated sterile males $(2.0 \pm 1.4 \%)$ were significantly lower than those of untreated flies $(6.2 \pm 5.5 \%)$. However, the recapture rates for both types of males were within acceptable limits for release-recapture studies with mass-reared and irradiated fruit flies. Up to day 4 after release the percentage recovery of sterile $B$. zonata males untreated and treated with $B$. bassiana was $76 \%$ and 81 $\%$, respectively; $90 \%$ of the recovered sterile flies from both groups were recovered up to $100 \mathrm{~m}$ from the release point, and only $4 \%$ at a distance between $150 \mathrm{~m}$ and $200 \mathrm{~m}$ from the release point. Our results suggest that sterile $B$. zonata males could potentially be used as vectors of $B$. bassiana to supplement suppression of this pest in a sterile insect release programme. Patel and Patel (1995) tasted the efficacy of modified trap (Methyl euginol alone) with conventional bait trap (Methyl euginol + DDVP) for traping fruit flies in a sapota (Manilkarazapota) orchard and reported that new designed trap "Patel fruit fly trap" proved equally effective. Liu and chen (1992)[10] reported that 10\% Cue lure was the most attractive mixture for luring males of both B. cucurbitae and Bactroceradorsalis as compared to methyl euginol. Sookar et al. [10] stuied attractiveness of the three proteinaceous substance (protein hydrolysate, Nu-lure and PIB-7 to Bactroceradorsalis and reported that protein hydrolysate was the most effective bait attracting $45.4 \%$ of adult females and $35.6 \%$ of males. Liu and Chen [11] determined the population dynamic of $\mathrm{B}$. dorsalis and $\mathrm{B}$. 
cucurbitae from 1987 to 1989 by fruit collection and male trap captured. The found that major hosts of B. dorsalis were wild strawberry, guava and peach whereas major host of B. cucurbitae were cultivated truck crops on farms. They further reported that during period of peak guava abundant, number of $B$. dorsalis increased on farm. During period of peak crop production, increased in habitats surrounding farms [12].

\section{Conclusion}

On the basis of present investigation, it was observed that Bactrocera zonata highly attracted to Methyl eugenol with sanitation Neem extract followed by Neem Extract + Methyl-Eugenol, Sanitation + MethylEugenol, Sanitation + Protein hydrolysis baits, Neem Extract + Protein hydrolysis baits, Without sanitation + Methyl-Eugenol and Without sanitation + Protein hydrolysis baits. Maximum population abundance of Bactrocera zonata were recorded at the end of September afterwards the population simultaneously declined upto end of October.

\section{Authors' contributions}

Conceived and designed the experiments: $\mathrm{M}$ Khan, SA Memon, BK Solangi \& G Jillani, Performed the experiments: A Uddin, SJ Shah \& E Aziz, Analyzed the data: M Khan, SA Memon \& BK Solangi, Contributed materials/ analysis/ tools: M Khan, K Jamil, N Ahmed, A Afzal \& A Raziq, Wrote the paper: M Khan, SA Memon, BK Solangi \& G Jillani.

\section{References}

1. Fletcher, (1987).Population fluctuations and interspecific competition between Tephritid flies attacking fruit crops in the New Valley oases, Egypt. Arch of Phytopathol and Plant Prot 43(7/9): 647-659.

2. Syed et al. (1970). Population fluctuations and interspecific competition between Tephritid flies attacking fruit crops in the New Valley oases, Egypt. Arch of Phytopathol and Plant Prot 43(7/9): 647659.

3. Kafi (1986). Final report for the project no PS-FAI-020-03 entitled "Study on biological means for controlling the Mediterranean fruit fly Ceratitiscapitata (Wiedemann) in New Valley Governorate" and submitted by the Academy of Scientific Research and Technology, Cairo, Egypt.

4. Jalaludin et al. (1999). Relative susceptibility of some fruits to the Mediterranean fruit fly, Ceratitis capitata (Wiedemann) and peach fruit fly, Bactrocera zonata (Saunders) (Diptera: Tephritidae) in Egypt. $J$ of Entomol and Zool Stu 14(4): 42-48.

5. Kumar et al. (1997). Effect of weather parameters on population dynamics of peach fruit fly, Bactrocerazonata (Saunders). Entomol 24(1): 81-84.

6. Irshad and Jilani (2003). Oviposition stimulants of the peach fruit fly Bactrocera zonata (Saunders) (Diptera: tephritidae) under laboratory conditions. J Egypt Soc Toxicol 34(1): 1-4.

7. Bhatti (1968). Agricultural Pests of India and Southeast Asia. Kalyani Publishers, New Delhi.

8. Solangi (2017). Le piegeage du carpocapce sexual de syntheses: primers results utilisables pour L. estimation des populations conduite de la lutte. Annales de Zoologie Ecologie Animale 7(1): 6180.

9. Bateman MA (1972). The ecology of fruit flies. Ann Rev Ent 17: 493-578.

10. Sookar et al. (2014). Fruit fly control and monitoring in the Near East: shared concern in a regional trans boundary. Proceedings of the 6th International Symposium on fruit flies of economic importance. 155-171, Stellenbosch, South Africa.

11. Liu and Chen (1992). Fruit fly control and monitoring in the Near East: shared concern in a regional trans-boundary. Proceedings of the 6th International Symposium on fruit flies of economic importance. Stellenbosch, South Africa, 155-171.

12. Vargas et al. (1990). Invasive phytophagous pests arising through a recent tropical evolutionary radiation: the Bactroceradorsalis complex of fruit flies. Ann Rev of Entomol 50: 293-319. 